\title{
KESESUAIAN POLA CELANA (PANTALON) SISTEM ALDRICH UNTUK PRIA DEWASA BERTUBUH IDEAL INDONESIA
}

\author{
Hanifatul Zikra ${ }^{1^{*}}$, Adriani ${ }^{2^{*}}$ \\ Program Studi Pendidikan Kesejahteraan Keluarga Jurusan Ilmu Kesejahteraan Keluarga \\ Fakultas Pariwisata dan Perhotelan \\ Universitas Negeri Padang \\ Jl. Prof. Dr. Hamta, Air Tawar Padang, Kel. Air Tawar Barat, Kec. Padang Utara, Kota Padang, Kode Pos 25171 \\ Sumatera Barat. Indonesia \\ Email: hanifatul94@gmail.com
}

\begin{abstract}
Abstrak
Pola pantalon sistem Aldrich belum diketahui apakah cocok untuk pria dewasa bertubuh ideal di Indonesia. Tujuan penelitian ini adalah untuk mendeskripsikan kelemahan, cara memperbaiki, dan penyesuaian pola pantalon sistem Aldrich pada bentuk tubuh pria ideal di Indonesia. Jenis penelitian yang digunakan adalah penelitian terapan. Objek penelitian yaitu pola pantalon sistem Aldrich yang diuji cobakan pada pria dewasa bertubuh ideal di Indonesia dengan tinggi $173 \mathrm{~cm}$, berat $64 \mathrm{~kg}$. Instrumen penelitian yang digunakan adalah angket memakai skala likerts. Penilaian dilakukan oleh 5 orang panelis, yaitu yang terampil dan ahli Busana Pria. Teknik analisis data yang digunakan adalah statistik deskriptif berupa perhitungan rumus persentase menggunakan Microsoft excel. Hasil penelitian menunjukkan pola pantalon sistem Aldrich mempunyai kelemahan pada bagian : 1)lingkar pinggang, 2)lingkar panggul, 3)kupnat belakang, 4)kantong samping. Kelemahan diperbaiki pada pola dan celana sehingga menghasilkan pola pantalon sistem Aldrich yang sesuai untuk pria dewasa bertubuh ideal Indonesia.
\end{abstract}

Kata Kunci: kesesuaian, pantalon, Aldrich, pria ideal.

\begin{abstract}
The pattern of Aldrich's pantaloon system is unknown whether it is suitable for ideal adult men in Indonesia. The purpose of this study was to describe weaknesses, to fix, and adjust the pattern of Aldrich's pantaloon system on the ideal male body shape in Indonesia. The type of research used is applied research. The object of the research is the pattern of Aldrich system pantaloon tested on ideal adult male in Indonesia with a height $173 \mathrm{~cm}$, weight $64 \mathrm{~kg}$. The instrument research used was questioner by using a Likerts scale. The assessment was carried out by 5 panelists, as well as people who have expertise and skilled menswear. The data analysis technique used is descriptive statistics in the form of calculating the percentage formula using Microsoft excel. The results showed the pantaloon pattern of the Aldrich system had weaknesses in the part: 1) waist circumference, 2) pelvic circumference, 3) a rear dart, 4) side pocket. The weaknesses were fixed on the pattern and pants to produce Aldrich system pantaloon pattern that is suitable for Indonesian ideal adult men.
\end{abstract}

Keywords: suitability, pantaloon, Aldrich, ideal men.

\section{PENDAHULUAN}

Salah satu dari sistem pola konstruksi yaitu pola sistem Aldrich. Pola sistem Aldrich atau Winefred Aldrich merupakan seorang desainer dan professor teknologi busana di Nottingnam Trent University, Inggris. Pola pantalon sistem Aldrich memiliki perbedaan dengan sistem pola yang lainnya. Dilihat dari cara pengambilan ukuran, ukuran yang digunakan dan teknik pembuatan pola. Ukuran yang dibutuhkan pada pembuatan pola celana pantalon sistem Aldrich yaitu, lingkar pinggang, lingkar panggul, panjang kaki, tinggi duduk, lebar bawah celana. makanannya Pada sistem pola lain, yaitu pola Soekarno menggunakan panjang celana untuk menentukan panjang celana yang diukur dari batas pinggang sampai dengan mata kaki, kemudian ukuran lingkar pesak (Soekarno 2016:19). Ditinjau dari ukuran yang digunakan untuk pembuatan pola pantalon sistem Aldrich terdapat perbedan ukuran yang digunakan pada sistem pola lainnya. Perbedaan tersebut terdapat pada ukuran panjang kaki yang diukur dari bawah garis pesak sampai dengan mata kaki, gunanya untuk menentukan panjang celana, tinggi duduk, untuk menentukan ukuran pesak (Aldrich 2015:156). Dilihat dari pembuatan pola, pola pantalon sistem Aldrich tidak menggunakan kupnat depan.

Sistem pola ini berasal dari Inggris dan belum diketahui apakah cocok untuk pria dewasa bertubuh ideal Indonesia. Menurut riset ilmiah yang dilakukan 


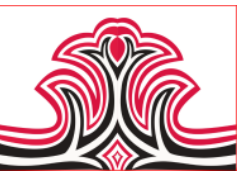

oleh Lembaga Penelitian Universitas Gajah Mada pada tahun 2001 tinggi rata-rata orang Indonesia 160$170 \mathrm{~cm}$. Pada benua Eropa seperti Inggris dan Belanda tinggi ideal $178 \mathrm{~cm}$. Dari segi ukuran lingkar pinggang, diketahui rata-rata lingkar pinggang pria Inggris $94-101 \mathrm{~cm}$ berdasarkan hasil penelitian Jurnal of British Medical Association (JBMA) tahun 20122013. Sedangkan lingkar pinggang rata-rata pria Indonesia adalah 78-80 cm (Soekarno, 2009:17). Menurut Aldrich (2015:5) ukuran rata-rata pria Inggris seperti : 1) lingkar dada 96-100 cm, 2) panjang punggung 43-44 cm, 3) lingkar leher 39-40 cm. sedangkan untuk ukran rata-rata pria Indonesia seperti yang diungkapkan Soekarno (2009:17) diantaranya 1) lingkar dada $92-95 \mathrm{~cm}, 2$ ) panjang punggung 40-41 $\mathrm{cm}, 3$ ) lingkar leher $37-38 \mathrm{~cm}$.

Dapat disimpulkan setiap manusia memiliki bentuk, ukuran dan tinggi tubuh yang berbeda satu sama lain. Ukuran tubuh pria Indonesia berbeda dengan ukuran tubuh orang Inggris, hal ini disebabkan karena beberapa faktor yang mempengaruhinya, salah satunya adalah faktor bawaan dari keturunan, orang keturunan Inggris memiliki tubuh yang lebih besar daripada orang Indonesia.

Untuk mengetahui berat badan ideal harus menggunakan rumus yang sesuai. Rumus yang digunakan untuk menentukan berat badan ideal menggunakan metode Brosca, seperti yang dikemukakan oleh Pierre Paul Brosca : Berat badan ideal $(\mathrm{kg})=\{$ tinggi badan $(\mathrm{cm})-100\}-\{$ [tinggi badan $(\mathrm{cm})-100] \times 10 \%$. Bila berat badan $<90 \%$ (kurus), > 10\% (gemuk), >20\% (obesitas). Jadi dari rumus tersebut dapat dikelahui bahwasanya seseorang pria Indonesia yang memiliki tinggi badan $173 \mathrm{~kg}$, berat badan $64 \mathrm{~cm}$. Maka berat badan ideal $=173 \mathrm{~cm}$ $-100-(173 \mathrm{~cm}-100) \times 10 \%=64 \mathrm{~kg}$.

Untuk menyesuaikan pola perlu dilakukan fitting terlebih dahulu. Menurut Hutton (1973:3) "Fitting adalah mengepas atau mencocokkan antara ukuran pola, kemudian try out pada bahan katun, mengepas pada bdan sipemakai, mengevaluasi hasil try out, selanjutnya memperbaiki kesalahan dan kelemahan pola".fitting dilakukan beberapa kali agar menghasilkan pola yang sesuai dan pas digunakan oleh pria dewas bertubuh ideal Indonesia.

Tujuan dari penelitian ini adalah untuk mengetahui: Menganalisis kelemahan terhadap pola pantalon sistem Aldrich untuk pria dewasa bertubuh ideal Indonesia, menganalisis cara memperbaiki kelemahan pola pantalon sistem Aldrich untuk pria dewasa bertubuh ideal Indonesia, dan menganalisis penyesuaian pola pantalon sistem Aldrich untuk pria dewasa bertubuh ideal Indonesia.
Gorga Jurnal Seni Rupa

Volume 08 Nomor 01 Januari-Juni 2019

p-ISSN: 2301-5942 | e-ISSN: 2580-2380

\section{KAJIAN TEORI}

\section{Pantalon Sistem Aldrich}

Menurut Mulyawan (1997:2) "Pola adalah suatu potongan kain atau kertas yang dipakai sebagai contoh untuk membuat pakaian, potongan kain atau kertas tersebut mengikuti bentuk/ ukuran badan tertentu".

Dapat disimpulkan pola adalah potongan kertas atau kain yang dipakai untuk pedoman dalam menggunting kain yang dibuat berdasarkan ukuran tubuh pemakai. Berdasarkan jenisnya pola dasar terdiri dari pola dasar pria yaitu pola dasar yang dibuat sesuai dengan ukuran pria. Pola dasar pria terdiri dari pola celana.

Menurut Poespo (2000:1) "Celana adalah pakaian luar yang menutupi badan dari pinggang ke mata kaki dalam dua bagian kaki yang terpisah". Pantalon adalah celana yang dipakai oleh laki-laki. Dapat disimpulkan celana pantalon merupakan pakaian bagian bawah yang dipakai oleh laki-laki,berbentuk lebar yang memanjang dari pinggang sampai pergelangan kaki, dan terdapat jahitan pesak pada tengah muka celana.

Untuk mendapatkan pola pantalon yang sesuai dengan bentuk tubuh dilakukan beberapa tahan pembuatannya, yaitu sebagai berikut : a) alat dan bahan dalam pembuatan pola (pita ukuran, kapur jahit, guntung, penghapus, pensil, kertas pola dan penggaris). b) mengambil ukuran badan (lingkar pinggang, lingkar panggul, panjang kaki bagian dalam, tinggi duduk, dan lebar bawah celana).

Pembuatan pola pantalon sistem Aldrich mengikuti langkah-langkah panduan sesuai dengan sistem Aldrich. Pembuatan pola dimulai dari pengambilan ukuran, persiapan alat-alat pembuatan pola, dan proses-proses pembauatn pola.

\section{Bentuk Tubuh Ideal Pria}

Dalam pembuatan busana hal yang perlu dilihat dan dinilai adalah bentuk tubuh model atau sipemakai. Tujuan menilai bentuk tubuh adalah utntuk mengetahui kelebihan atau kekurangan dari bentuk tubuh sipemakai sehingga dapat melakukan penyeseuaian.

Menurut Pratiwi (2001:6) "Bentuk tubuh manusia digolongkan menjadi lima macam bentuk tubuh yaitu normal atau ideal, gemuk pendek, kurus pendek, tinggi gemuk, dan tinggi kurus “.

Ukuran tubuh pria Indonesia berbeda dengan ukuran tubuh orang Inggris, hal ini disebabkan karena beberapa faktor yang mempengaruhinya, salah 


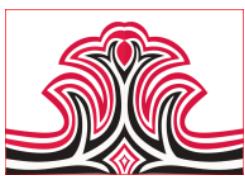

satunya adalah faktor bawaan dari keturunan, orang keturunan Inggris memiliki tubuh yang lebih besar daripada orang Indonesia.

Untuk mengetahui berat badan ideal harus menggunakan rumus yang sesuai. Rumus yang digunakan untuk menentukan berat badan ideal menggunakan metode Brosca, seperti yang dikemukakan oleh Thomas (2008:79)

Berat badan ideal $(\mathrm{kg})=\{$ tinggi badan $(\mathrm{cm})-100\}-$ $\{[$ tinggi badan $(\mathrm{cm})-100] \times 10 \%\}$

\section{Keterangan:}

Batas ambang yang diperolah adalah $+10 \%$.

1) Apabila $>10 \%$ sudah kegemukan.

2) Apabila $<90 \%$ dikatakan kurus.

3) Apabila diatas $20 \%$ sudah terjadi obesitas.

Selain bertubuh ideal sesuai dengan judul penulis penyesuaian pola pantalon untuk pria dewasa bertubuh ideal Indonesia. Pria dewasa yang dijadikan model berumur 23 tahun, sesuai dengan pendapat Harlock (1990:246) masa dewasa terbagi menjadi tiga periode yaitu : 1) Masa dewasa awal dimulai pada umur 18 tahun sampai 40 tahun. 2) Masa dewasa madya dari umur 40 tahun sampai 60 tahun. 3) Masa dewasa akhir dari 60 tahun sampai dengan kematian. Penulis memakai model dengan umur 23 tahun yang termasuk pada masa dewasa awal.

\section{Kesesuaian Pola}

Pola pantalon sistem Aldrich di sesuaikan dengan tubuh ideal pria Indonesia. Untuk mengetahui kesesuaian pola pola pantalon sistem Aldrich pada pria dewasa bertubuh ideal sangat diperlukan dengan cara melakukan pengepasan atau fitting beberapa kali untuk mendapatkan hasil yang pas. Menurut Poespo (2000:72) "Fitting.menunjukkan pada sempit dan longgarnya sebuah bentuk busana dalam hubungannya dengan orang yang memakainya. Busana atau pakaian yang enak dipakai adalah yang berukuran tepat dan tidak kesesakkan ataupun kedodoran/longgar bila dikenakan". Tujuan fitting dalam pembuatan busana adalah: mengetahui hasil pola pakaian, melihat kekurangan pola pakaian, untuk mendapatkan hasil yang benar-benar tepat sesuai bentuk tubuh sipemakai.

\section{METODE PENELITIAN}

Jenis penelitian ini adalah penelitian terapan. Objek penelitian adalah pola pantalon sistem Aldrich yang diujicobakan pada pria dewasa bertubuh ideal Indonesia yang berumur 23 tahun, tinggi $173 \mathrm{~cm}$, berat $64 \mathrm{~kg}$. variabel penelitian yaitu, kesesuaian pola pantalon sistem Aldrich untuk pria dewasa bertubuh
Gorga Jurnal Seni Rupa

Volume 08 Nomor 01 Januari-Juni 2019

p-ISSN: 2301-5942 | e-ISSN: 2580-2380

ideal Indonesia, dengan indikator nya adalah pola pantalon.

Prosedur penelitian terdiri dari 4 tahapan yaitu : persiapan, pelaksanaan, penyelesaian dan fitting. Instrument penelitian menggunakan format penilaian yang digunakan berupa skala likert yaitu berisikan alternatif 4 pilihan jawaban, yaitu : Sangat Sesuai (SS) dengan skor 4, Sesuai (S) dengan skor 3, Kurang Sesuai (KS) dengan skor 2, Tidak Sesuai (TS) dengan skor 1.

Untuk melakukan uji coba instrumen menggunakan validitas logis, sedangkan kontrol validasi dilakukan dengan bahan yang sama, pengambilan ukuran sesuai dengan sistem pola, setiap langkah pembuatan pola dicek ketepatan ukuran, penilaian dikalukan dengan cara menyesuaikan uji coba pola pantalon pada pria dewasa bertubuh ideal, penilaian dikaukan oleh tim penilai yang ahli dalam bidang pola, pada tiap item yang sudah sangat sesuai dengan skor 4, penilaian tidak perlu lagi dilakukan fitting selanjutnya.

Teknik analisis data menggunakan analisis statistik deskriptif. dengan melihat modus, median, dan persentase. Menurut Sugiyono (2012:29) mengatakan bahwa "Statistik deskriptif adalah yang berfungsi untuk mendeskripsikan atau memberi gambaran terhadap objek yang diteliti melalui data sampel atau polulasi sebagaimana adanya, tanpa melakukan analisis dalam membuat kesimpulan yang berlaku untuk umum".

Dalam penelitian ini penulis menggunakan perhitungan rumus persentase (Sudjana,2011:43).

$\mathrm{P}=\underline{\mathrm{F}} \times 100 \%$

$\mathrm{N}$

Keterangan:

$\mathrm{P}=$ pesentase

$\mathrm{F}=$ Jumlah

$\mathrm{N}=$ Jumlah banyak skor

Data diolah menggunakan Microsoft Excel, kemudian data yang diperoleh dikelompokkan dalam 5 kategori standar penilaian yang dikemukan oleh Arikunto (2010:44) yaitu.

$\begin{array}{ll}81 \%-100 \% & =\text { Sangat Tinggi } \\ 61 \%-80 \% & =\text { Tinggi } \\ 41 \%-60 \% & =\text { Sedang } \\ 21 \%-40 \% & =\text { Rendah } \\ 0 \%-20 \% & =\text { Sangat Rendah }\end{array}$




\section{HASIL DAN PEMBAHASAN}

\section{Hasil}

Pola pantalon sistem Aldrich yang disesuaikan pada bentuk tubuh ideal pria dengan aspek yang dinilai sebanyak 11 item. Penilaian pola pantalon sesuai bentuk tubuh ideal pria dilakukan dengan fitting sebanyak 2 kali. Hasil pengolahan data pada fitting I ditinjau dari modus, median dan persentase jawaban masing-masing panelis yang dinilai kurang sesuai ada 4 item. Fitting II ditinjau dari modus, median, dan persentase jawaban masing-masing panelis semua item dinilai sangat sesuai. Maka pada fitting II pola pantalon sudah sesuai dengan pria bertubuh ideal Indonesia.

Hasil penelitian kesesuaian pola pantalon sistem Aldrich untuk pria dewasa bertubuh ideal Indonesia sebagai berikut : a) Lingkar pinggang, dengan hasil penilaian $($ modus $=2$, median $=2$, dan persentase $=45 \%$ ), pada item lingkar pinggang dinilai kurang sesuai karena penambahan kelonggaran pada lingkar pinggang sebanyak $9 \mathrm{~cm}$ menyebabkan lingkar pinggang menjadi kebesaran. b) Lingkar panggul, dengan hasil penilaian (modus-2, median=2, dan persentase $=65 \%$ ), pada item lingkar panggul dinilai kurang sesuai karena penambahan $11 \mathrm{~cm}$ untuk kelonggaran pada lingkar panggul menyebabkan panggul menjadi kebesaran. c) Kupnat belakang, dengan hasil penilaian dengan (modus $=2$, median=2, dan persentase $=60 \%$ ), pada item kupnat belakang dinilai kurang sesuai karena kupnat belakang terlalu panjang $12 \mathrm{~cm}$, sehingga pada pembuatan kantong belakang/klep kupnat jadi kelihatan. d) Kantong samping, dengan hasil penilaian (modus $=2$, median $=3$, dan persentase $=60 \%$ ), pada item kantong samping dinilai kurang sesuai karena ukuran kantong terlalu kecil/sempit.

Cara memperbaiki pola pantalon sistem Aldrich adalah dengan cara penyesuaian. Penyesuaian pola dilakukan dengan menggunakan tanda pola. Tanda pola yang digunakan untuk mengecilkan pola ditandai dengan xxxxx sedangkan untuk memperbesar pola ditandai dengan ///// (Ernawati 2008:249). Berikut adalah cara penyesuaian pola pantalon sistem Aldrich setelah fitting I, memperbaiki pola sesuai kelemahan dengan cara berikut:
Gorga Jurnal Seni Rupa

Volume 08 Nomor 01 Januari-Juni 2019

p-ISSN: 2301-5942 | e-ISSN: 2580-2380

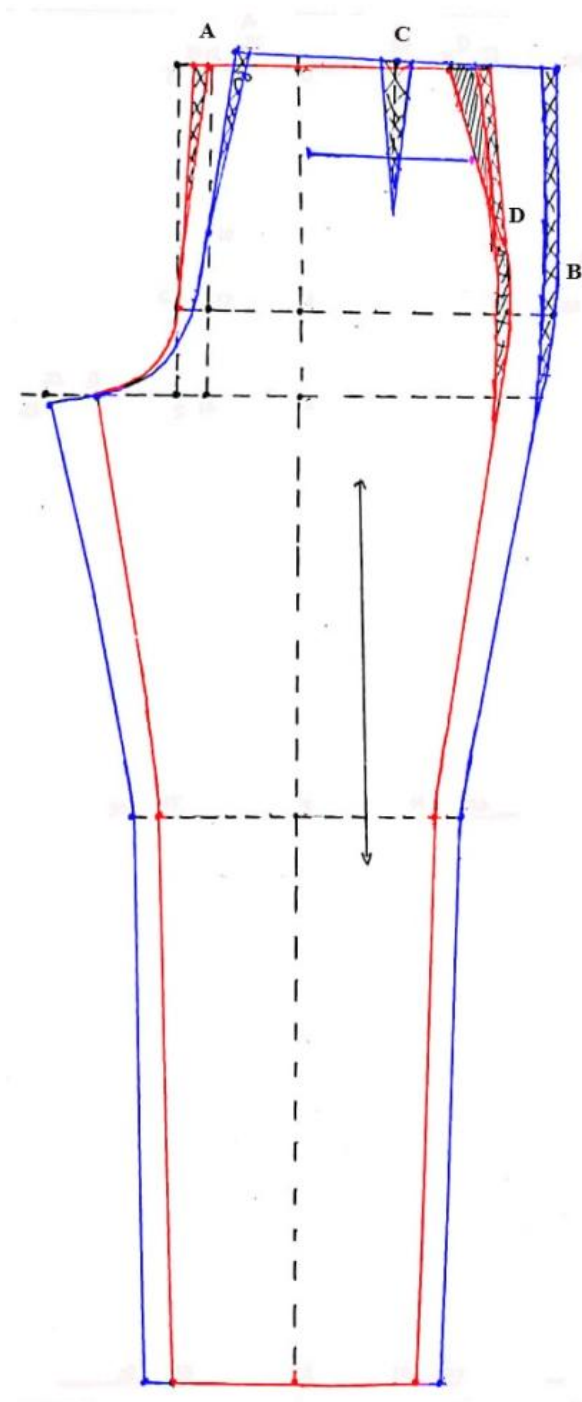

Gambar 1. Hasil Penyesuaian Pola Pantalon (Sumber: Hanifatul Zikra, 2018)

Hasil dari penyesuaian pola pantalon sistem Aldrich yaitu: a) Penyesuaian lingkar pinggang. Lingkar pinggang perlu diperbaiki, dengan kelemahan lingkar pinggang besar $9 \mathrm{~cm}$. Cara memperbaikinya yaitu lingkar pinggang dikurang $1 \mathrm{~cm}$ di bagian sisi depan dan belakang dan $1 \mathrm{~cm}$ dibagian tengah pesak depan dan belakang. b) Penyesuaian lingkar panggul. Lingkar panggul perlu diperbaiki, dengan kelemahan lingkar panggul besar. Cara memperbaikinya yaitu lingkar panggul dikurangi $1 \mathrm{~cm}$ dibagian depan dan belakang. c) Penyesuaian kupnat belakang. Kupnat belakang perlu diperbaiki, dengan kelemahan kupnat terlalu panjang. Cara memperbaikinya yaitu : kupnat belakang dikurangi $2 \mathrm{~cm}$. d) Penyesuaian kantong samping. Kantong samping perlu diperbaiki, dengan kelemahan kantong samping sempit atau kurang panjang. Cara memperbaikinya yaitu : panjang kantong samping ditambah $2 \mathrm{~cm}$. 
Dari uraian diatas dapat dilihat bahwa pola pantalon sistem Aldrich pada fitting I berdasarkan modus, median, dan persentase, terdapat beberapa kelemahan sebanyak 4 item yaitiu : lingkar pinggang, lingkar panggul, kupnat belakang, dan kantong samping. Kesesuian pola pantalon sistem Aldrich terdapat pada fitting II, karena semua item berdasarkan modus, median dan persentase dinilai sangat sesuai oleh panelis. Jadi, berdasarkan penilaian pada fitting II pola pantalon sistem Aldrich di golongkan kedalam kategori sangat tinggi dan dapat digunakan pada pria bertubuh ideal Indonesia.

\section{Pembahasan}

Kelemahan pola pantalon sistem Aldrich. Berdasarkan hasil penelitian ditemukan 4 kelemahan pada pola pantalon sistem Aldrich untuk pria dewasa bertubuh ideal Indonesia pada fitting I. untuk penyesuaian pola pantalon sistem Aldrich untuk pria dewasa bertubuh ideal Indonesia membutuh kan 2 kali fitting sehingga pola pantalon sistem Aldrich sesuai untuk pria dewasa bertubuh ideal Indonesia.

Cara memperbaiki pola pantalon sistem Aldrich. Berdasarkan hasil analisis penilaian pada pola pantalon sistem Aldrich untuk pria dewasa bertubuh ideal Indonesia dengann modus 2, median 3, dan persentase $71 \%$. Berdasarkan hasil tersebut pola pantalon dikategorikan sesuai untuk pria dewasa bertubuh ideal Indonesia, tetapi masih terdapat 4 item dari 11 item yang dinilai kurang sesuai oleh panelis, oleh sebap itu pola celana perlu dilakukan perbaikannya.

Penyesuaian pola pantalon sistem Aldrich untuk pria dewasa bertubuh ideal Indonesia dilakukan dengan cara perbaikan pada proses pembuatan pola celana yaitu : lingkar pinggang, lingkar panggul, kupnat belakang, dan kantong samping.

Penyesuaian pola pantalon sistem Aldrich. Menurut Alwi (2008) berpendapat penyesuaian adalah proses, cara, perbuatan menyesuaikan, sedangkan kesesuaian adalah kecocokan, keselarasan. Penyesuaian pola bertujuan untuk mendapatkan kesesuaian pola pantalon. Kesesuaian pola pantalon sistem Aldrich untuk pria dewasa bertubuh ideal Indonesia terdapat pada fitting II, karena pola celana dinilai sangat sesuai oleh penelis berdasarkan modus 4, median 4, dan persentase $92 \%$.
Gorga Jurnal Seni Rupa

Volume 08 Nomor 01 Januari-Juni 2019

p-ISSN: 2301-5942 | e-ISSN: 2580-2380

\section{KESIMPULA DAN SARAN}

\section{Kesimpulan}

Berdasarkan hasil penelitian kelemahan pola pantalon sistem Aldrich untuk pria dewasa bertubuh ideal Indonesia setelah dilakukan fitting I yaitu : a) lingkar pinggang, 2) lingkar panggul, 3) kupnat belakang, 4) kantong samping. Penyesuaian pola pantalon sistem Aldrich. Penyesuaian pola pantalon sistem Aldrich untuk pria dewasa bertubuh ideal Indonesia sebagai berikut : a) lingkar pinggang besar $9 \mathrm{~cm}$, cara memperbaikinya dengan mengurangi $1 \mathrm{~cm}$ pada bagian sisi depan dan belakang, $1 \mathrm{~cm}$ pada bagian tengah pesak depan dan belakang, b) lingkar panggul besar, cara memperbaikinya dengan mengurangi $1 \mathrm{~cm}$ pada bagian sisi depan dan belakang panggul, b) kupnat belakang panjang, dengan cara menguragi panjang kupnat $2 \mathrm{~cm}, \mathrm{c}$ ) kantong samping sempit atau kurang panjang, cara memperbaikinya dengan menambah panjang kantong $2 \mathrm{~cm}$.

\section{Saran}

Berdasarkan hasil penelitian yang telah disimpulkan, maka peneliti memberi nsaran sebagai berikut :

Bagi mahasiswa, mahasiswa yang melakukan penelitian eksperimen pola selanjutnya pada saat melakukan penyesuaian pola harus memperhatikan tanda-tanda pola dengan benar dan teliti. Bagi peneliti selanjutkan disaat pengambilan ukuran harus mengetahui cara pengambilan ukuran sesuai dengan sistem pola, karena setiap sistem pola memiliki cara masing-masing yang berbeda. Sebagai refensi dalam pembuatan busana pria, khususnya pantalon. Bagi dosen, diharapkan bisa menerapkan pola pantalon sistem Aldrich dalam mata kuliah busana pria. Sebagai rujukan dalam pembuatan bahan ajar

\section{DAFTAR RUJUKAN}

Aldrich Winefred. (2015). Terampil Merancang Pola Busana Pria Dengan Sistem Metrik. Jakarta: Libri.

Alwi, Hasan. (2008).Kamus besar bahasa indonesia. Jakarta: PT Gramedia Pustaka Utama.

Arikunto, Suharsimi. (2010). Prosedur Penelitian. Jakarta: Rineka Cipta.

Harlock. E.B. (1990). Psikologi Perkembangan Edisi 5.Jakarta: Erlangga.

Ernawati, dkk. (2008). Tata Busana Jilid 3. Jakarta: Departemen Pendidikan Nasional.

Hutton, Jessie. (1973). Fashion Tailoring New York New York: Golden Press.

Poespo, Geot. (2000). Aneka Celana (Pants). Yogyakarta: Kanisius.

Poespo, Geot. (2000). Istilah Fashion. Jakarta: PT Gramedia Pustaka.

Mulyawan, Porrie. (1997). Konstruksi Pola Busana Wanita. Jakarta. BPK Gunung Mulia. 
Pratiwi, Djati. (2001). Pola Dasar Dan Pecah Pola. Yogyakarta: Kanisius.

Soekarno. (2016). Buku Penuntun Membuat Pola Busana Tingkat Mahir. Jakarta: Gramedia Pustaka..

Sugiyono. (2009). Metodologi Penelitian. Bandung: Alfabeta.

Sudjana, Anas. (2011). Pengantar Evaluasi Pendidikan. Jakarta: PT. Grafindo Persada.

Thomas. (2008). Sistem Pengukuran Berat Badan dan Tinggi Badan Menggunakan Mikrokontelar AT89531, 10(2), 5-9. 